\title{
Investigation The Effect of Different Levels of Dry Sugar Beet Pulp mixed Concentrate Feeds on Cadmium Levels in Rabbit Slaughter Products
}

\author{
Olena TYTARIOVA ${ }^{1}$, Aamir IQBAL ${ }^{*}$, Leonid DYACHENKO ${ }^{1}$, Vitalii BOMKO', \\ Oksana KUZMENKO' ${ }^{1}$, Oleksandr CHERNIAVSKYI ${ }^{1}$, Serhii BABENKO', \\ Mykhailo SLOMCHYNSKYI ${ }^{1}$, Oksana TSEKHMISTRENKO ${ }^{1}$, İbrahim Sadi ÇETİNGÜL ${ }^{2}$, \\ Eyüp Eren GÜLTEPE², İsmail BAYRAM²
}

\author{
${ }^{1}$ Department of Technology of Feed, Feed Additives and Animal Feeding, Faculty of Biological Technology, Bila Tserkva National \\ Agrarian University, Bila Tserkva, Ukraine \\ ${ }^{2}$ Department of Animal Nutrition and Nutritional Diseases, Faculty of Veterinary Medicine, Afyon Kocatepe University, \\ Afyonkarabisar, Turkey
}

\begin{abstract}
Commercial concentrated feeds are traditionally a major component of rabbit diets which contain Cadmium element in quantities above generally accepted level. This toxic trace element can accumulate in meat, kidneys, liver, bones and spleen of rabbits. Consumption of such meat and by-products will contribute to the accumulation of Cadmium in the human body, which may lead to a number of pathological changes. In this study, 100 young rabbits-analogues of silver breed were selected, and divided into 5 groups, 20 rabbits in each group: the 1st group was the control group, the $2 \mathrm{nd}$, 3 rd, 4 th and 5 th were experimental with total 60 days duration period. Results showed the smallest content of Cadmium in slaughter products was observed in the rabbits at 5th experimental group. In conclusion, the course of the experiment, it has been established that supplementation into the rabbit's mixed fodder of dry sugar beet pulp contributes to reducing the level of Cadmium accumulation in slaughter products. It has also been noted that most of Cadmium is excreted with feces, that is, it is not absorbed into the bloodstream and does not have a negative effect on the body of the rabbit.
\end{abstract}

Keywords: Cadmium, dry sugar beet pulp, slaughter products, rabbits, mixed fodder

$* * *$

Kadmiyum İlaveli Konsantre Yemlere Farklı Düzeylerde Kuru Şeker Pancarı Posası Katılmasının Tavşanların Kesim Ürünlerinde Kadmiyum Seviyelerine Etkisinin Araştırılması

ÖZ

Ticari konsantre yemler genellikle kabul edilen seviyenin üzerinde kadmiyum elementini içeren tavşan diyetlerinin ana bileşenidir. Bu toksik iz element, tavşanların etlerine, böbreklerde, karaciğerde, kemiklerde ve dalaklarında birikebilir. Bu tür et ve yan ürünlerinin tüketimi, insan vücudunda kadmiyum birikimine katkıda bulunabilir ve bu durum bir takım patolojik değişikliklere neden olabilir. Bu çalışmada, 100 adet gümüş ırkın analoğu genç tavşan kullanılmıştır. Tavşanlar, her birinde 20 adet olmak üzere 5 gruba ayrılmıştır. Gruplar 1 kontrol ve 4 deneme grubu olacak şekilde düzenlenmiştir. Araştırma 60 gün boyunca sürdürülmüştür. Sonuçlar, 5. deneme grubundaki tavşanlarda, kesim sonrası elde edilen karkasta ve bazı iç organlarda en az düzeyde kadmiyum içeriğinin tespit edildiğini göstermiştir. Sonuç olarak, deneme boyunca, $0.04 \mathrm{mg} / \mathrm{kg}$ düzeyindeki kadmiyum katkılı rasyonlara artan düzeylerde kuru şeker pancarı ilavesinin, karkas ve bazı iç organlarda kadmiyum seviyesinin azaltılmasına katkıda bulunduğu tespit edilmiştir. Ayrıca kadmiyumun çoğunun dışkı ile atıldığ1, yani kan dolaşımına emilmediği ve tavşanın vücudu üzerinde olumsuz bir etkiye sahip olmadığı da kaydedilmiştir.

Anahtar Kelimeler: Kadmiyum, kuru şeker pancarı posası, kesim ürünleri, tavşan, karma yem

To cite this article: Tytariova O. Iqbal A. Dyachenko L. Bomko V. Kuzmenko O. Cherniavskyi O. Babenko S. Slomchynsky M. Cetingül İS. Gültepe E.E. Bayram I. Investigation the Effect of Different Levels of Dry Sugar Beet Pulp Mixed Concentrate Feeds on Cadmium Levels in Rabbit Slaughter Products. Kocatepe Vet J. (2020) 13(2):98-103

Submission: 30.11.2019 Accepted: 20.03.2020 Published Online: 24.04.2020

ORCID ID; OT: 0000-0003-4820-809X, AI: 0000-0003-4473-2329, LD: 0000-0003-4615-0277, VB: 0000-0001-5558-6924, OK: 0000-0003-4553-9950, OC: 0000-0003-0713-6587, SB: 0000-0001-5131-4999, MS: 0000-0001-5197-2684,

OT: 0000-0003-0509-4627, İSÇ: 0000-0002-7608-6176, EEG: 0000-0002-2404-1232, İB: 0000-0002-2404-1232

*Corresponding author e-mail: aamir_vet@yahoo.com 


\section{INTRODUCTION}

Cadmium (Cd) is a highly persistent environmental toxicant that exhibits higher rates of soil-to-plant transfer than other toxic heavy metals, such as lead $(\mathrm{Pb})$ and mercury $(\mathrm{Hg})$, making $\mathrm{Cd}$ a food-chain contaminant of great concern. Further, Cd oxide $(\mathrm{CdO})$, which is a highly bioavailable form of $\mathrm{Cd}$, is present in cigarette smoke and polluted air, contributing to elevated $\mathrm{Cd}$ concentrations in blood, urine, and tissues of smokers, compared with nonsmokers of similar age and gender (McLaughlin et al., 1999). For several decades, the problem of reducing the content of heavy metals, in particular Cadmium, in the environment is an acute problem in the world (Wu et al., 2016). The toxicity of this chemical element has been proved by numerous studies (Carson et al., 2018). Cadmium primarily affects the kidneys (Johri et al., 2010), respiratory and cardiovascular systems, and spermatogenesis (Rahimzadeh et al., 2017). Bones undergo less noticeable changes, although under the action of elevated doses of Cadmium, they become brittle and fragile (Chen et al., 2011). Additionally, carcinogenic effects of Cadmium on human body have been proven in recent studies (Adams et al., 2014; Eriksen et al., 2015). So it is very important not to allow the accumulation of heavy metals, in human diet prevent its accumulation in the human body. The major sources of Cadmium in the human body are food, water and air (Nordberg, 2004).

The idea of using of sugar beet pulp as a sorbent of heavy metals is not new. A number of studies prove the effectiveness of sugar beet pulp in such applications as water purification (Pehlivan et al, 2008). The results of a number of studies have also confirmed the detoxifying effect of pectin on poisoning with Lead (Khotimchenko et al., 2007). There are reports of a decrease in the level of heavy metals in chicken broiler meat after the feeding with citrus pectin (Temiraev et al., 2017).

Previously, we have published the results of studies conducted on pigs that showed that the use of beets, apple and sugar beet pulp in pig's feeding contributes to the decrease of heavy metals accumulation in their slaughter products (Dyachenko et al., 2015, 2017).

Since pork is less used for feeding of children and sick people belonging to the most vulnerable populations, our experiments were aimed at investigating the effects of different levels of beet pulp in mixed fodder on the accumulation of heavy metals in young rabbits grown for meat.

\section{MATERIALS and METHODS}

The current study was performed at the Experimental Animal Research farm of Bila Tserkva National
Agrarian University Ukraine after the approval of the Local Ethics Committee of the Faculty of Veterinary Medicine under approval No: 00001/01; dated: 30/05/2016.

\section{Experimental design and management}

To conduct scientific and economic experiment, 100 young rabbits-analogues of silver breed were selected, and divided into 5 groups, 20 rabbits in each group: the 1 st group was the control group, the 2 nd, 3 rd, 4 th and 5 th were experimental ones (Table1). During the comparative period, within 15 days, rabbits were fed with a full-fodder feed № 1, in which the dry beet pulp was absent. In the main period, the animals in the control group were got feeding of this mixed fodder, and the rabbits of the 2nd - 5th experimental groups got the mixed fodder where the share of barley was replaced with dry beet pulp according to the Table 2. The chemical composition and nutrition of the complete feed corresponded to the established requirements (Maertes at all. 2004).

\section{Data Collection and Analyses}

In the course of the experiment, the rabbits were kept individually in cages equipped with bunker feeders. Mixed fodders were used in the form of solid granules with a diameter of $5 \mathrm{~mm}$. Animals of all groups had free access to food and water during 24 hours. The slaughter was carried out in accordance with the relevant animal protection regulations during the slaughter procedure (European Communities, 2009). The content of Cadmium in mixed fodders, excrements and rabbit slaughter products was determined using an atomic adsorption spectrophotometer.

\section{Statistics}

The model assumptions of normality and homogeneity of variance were examined by ShapiroWilk and Levene tests, respectively. The statistical analysis was performed with MedCalc software (MedCalc Software bvba, Ostend, Belgium, version 17.5). One-way ANOVA was used for group comparison followed by Tukey-Kramer for post-hoc. All data were expressed as mean \pm SEM. The significance level was considered as $\mathrm{p}<0.05$.

\section{RESULTS}

The main purpose of dry beet pulp as a sorbent of heavy metals was to reduce the level of fasciation of Cadmium in the body of rabbits. The results of the balance study showed that at the same level of consumption of Cadmium in all experimental groups, the majority of this trace element was excreted with feces and lesser with urine (Table 3). 
The inclusion of dry beet pulp into the mixed fodder not only improved the growth of rabbits, but also reduced the flow of Cadmium into the products of their slaughter. At the mass fraction of dry pulp in the mixed fodder of $3 \%$ the Cadmium fixation in the rabbit's bodies of the 2nd experimental group decreased by $3.43 \%$ compared to the control one. With the $12 \%$ mass fraction of dry pulp in the feed (the 5th experimental group) the quantity of Cadmium in the body of rabbits decreased to $8.68 \%$, which is $9.31 \%$ less than control group (Table 4 ).
During the main experimental period the animals in test groups, according to the average daily increments, dominated their peers from the 1 st control group (Fig. 1 and Fig. 2). According to Fig. 1 in the first group, highest assimilation of Cadmium in the body of rabbits, $\%$ of consumed however, in other groups it decrease drastically. According to Fig. 2, in the 3rd experimental group, highest average daily increments (g) in the rabbits were observed as compared to other experimental and control group.

Table 1. In vivo experiment schedule.

\begin{tabular}{lcc}
\hline \multirow{2}{*}{ Group } & \multicolumn{2}{c}{ Feeding terms and conditions } \\
\cline { 2 - 3 } & $\begin{array}{c}\text { Comparative (preparatory) period } \\
\text { (15 days) }\end{array}$ & $\begin{array}{c}\text { Main period } \\
\text { (60 days) }\end{array}$ \\
\hline 1 - control group & Mixed fodder (MF) 1 & MF 1 (Cadmium content $0.04 \mathrm{mg} / \mathrm{kg})^{1}$ \\
2 - experimental group & MF 1 & MF 2 (Cadmium content $0.04 \mathrm{mg} / \mathrm{kg})^{1}$ \\
3 - experimental group & MF 1 & MF 3 (Cadmium content $0.04 \mathrm{mg} / \mathrm{kg})^{1}$ \\
$4-$ experimental group & MF 1 & MF 4 (Cadmium content $0.04 \mathrm{mg} / \mathrm{kg})^{1}$ \\
5 - experimental group & MF 1 & MF 5 (Cadmium content $0.04 \mathrm{mg} / \mathrm{kg})^{1}$ \\
\hline${ }^{1}$ Natural content in feed & &
\end{tabular}

Table 2. Composition of the Concentrated Feeds, \%

\begin{tabular}{lccccc}
\hline Item & MF No 1 & MF No 2 & MF No 3 & MF No 4 & MF No 5 \\
\hline Barley grain & 19 & 16 & 13 & 10 & 7 \\
Corn, grain & 10 & 10 & 10 & 10 & 10 \\
Wheat, grain & 18 & 18 & 18 & 18 & 18 \\
Soybean meal & 10 & 10 & 10 & 10 & 10 \\
Alfalfa hay flour & 30 & 30 & 30 & 30 & 30 \\
Dry sugar beet pulp & - & 3 & 6 & 9 & 12 \\
Meat and bone meal & 5 & 5 & 5 & 5 & 5 \\
Salt (NaCl) & 5 & 5 & 5 & 5 & 5 \\
Chalk (CaCO3) & 1 & 1 & 1 & 1 & 1 \\
Premix Axelarat & 2 & 2 & 2 & 2 & 2 \\
Total & 100 & 100 & 100 & 100 & 100 \\
\hline
\end{tabular}

Table 3. Balance of Cadmium in the body of young rabbits, $\mu \mathrm{g}, \bar{O}_{ \pm} S_{\overline{\tilde{o}}}(\mathrm{n}=3)$

\begin{tabular}{lcclcc}
\hline Item & \multicolumn{5}{c}{ Group } \\
\hline & Control & Experimental & Experimental & Experimental & Experimental \\
\hline Consumed with feed & $\mathbf{1}$ & $\mathbf{2}$ & $\mathbf{3}$ & $\mathbf{4}$ & $\mathbf{5}$ \\
Consumed with water & $0.00 \pm 0.304$ & $5.94 \pm 0.173$ & $6.15 \pm 0.131$ & $5.92 \pm 0.130$ & $5.88 \pm 0.148$ \\
Secreted with excrements & $2.67 \pm 0.145$ & $2.90 \pm 0.153$ & $3.47 \pm 0.088^{*}$ & $3.47 \pm 0.067^{*}$ & $3.43 \pm 0.088^{*}$ \\
Secreted with urine & $2.37 \pm 0.033$ & $2.30 \pm 0.058$ & $2.07 \pm 0.088$ & $2.00 \pm 0.116$ & $2.07 \pm 0.088$ \\
Assimilated & $1.11 \pm 0.132$ & $0.88 \pm 0.054$ & $0.77 \pm 0.053$ & $0.60 \pm 0.064^{*}$ & $0.52 \pm 0.045^{*}$ \\
\hline
\end{tabular}


Table 4. Cadmium content in young rabbit slaughter products, $\mu \mathrm{g}, \bar{O}_{ \pm} \pm S_{\bar{o}}(\mathrm{n}=3)$

\begin{tabular}{|c|c|c|c|c|c|}
\hline \multirow[t]{2}{*}{ Item } & \multicolumn{5}{|c|}{ Group } \\
\hline & Control & Experimental & Experimental & Experimental & Experimental \\
\hline & 1 & 2 & 3 & 4 & 5 \\
\hline Kidney & $181.7 \pm 4.06$ & $164.7 \pm 3.93 *$ & $147.0 \pm 4.16^{* *}$ & $143.0 \pm 4.04 * *$ & $127.0 \pm 3.79 * * *$ \\
\hline Bones & $153.3 \pm 2.73$ & $136.3 \pm 2.03^{* *}$ & $126.3 \pm 2.33 * *$ & $113.3 \pm 2.03^{* * *}$ & $109.3 \pm 2.33^{* * *}$ \\
\hline Liver & $106.3 \pm 2.91$ & $89.3 \pm 2.33^{*}$ & $85.0 \pm 2.31 * *$ & $75.7 \pm 2.03^{* *}$ & $65.3 \pm 1.76^{* * *}$ \\
\hline Meat & $28.7 \pm 0.88$ & $24.7 \pm 0.88^{*}$ & $22.3 \pm 0.88^{* *}$ & $20.7 \pm 0.88^{* *}$ & $19.3 \pm 1.20^{* *}$ \\
\hline
\end{tabular}

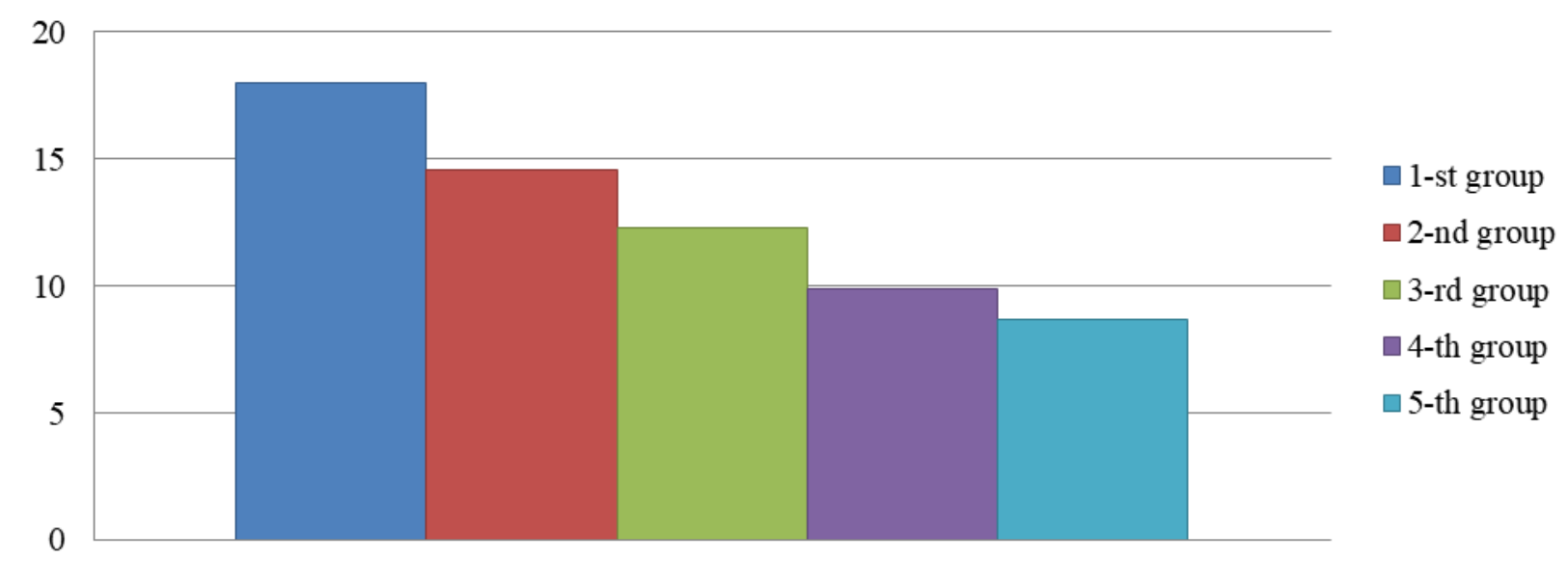

Figure 1. Assimilation of Cadmium in the body of rabbits, $\%$ of consumed

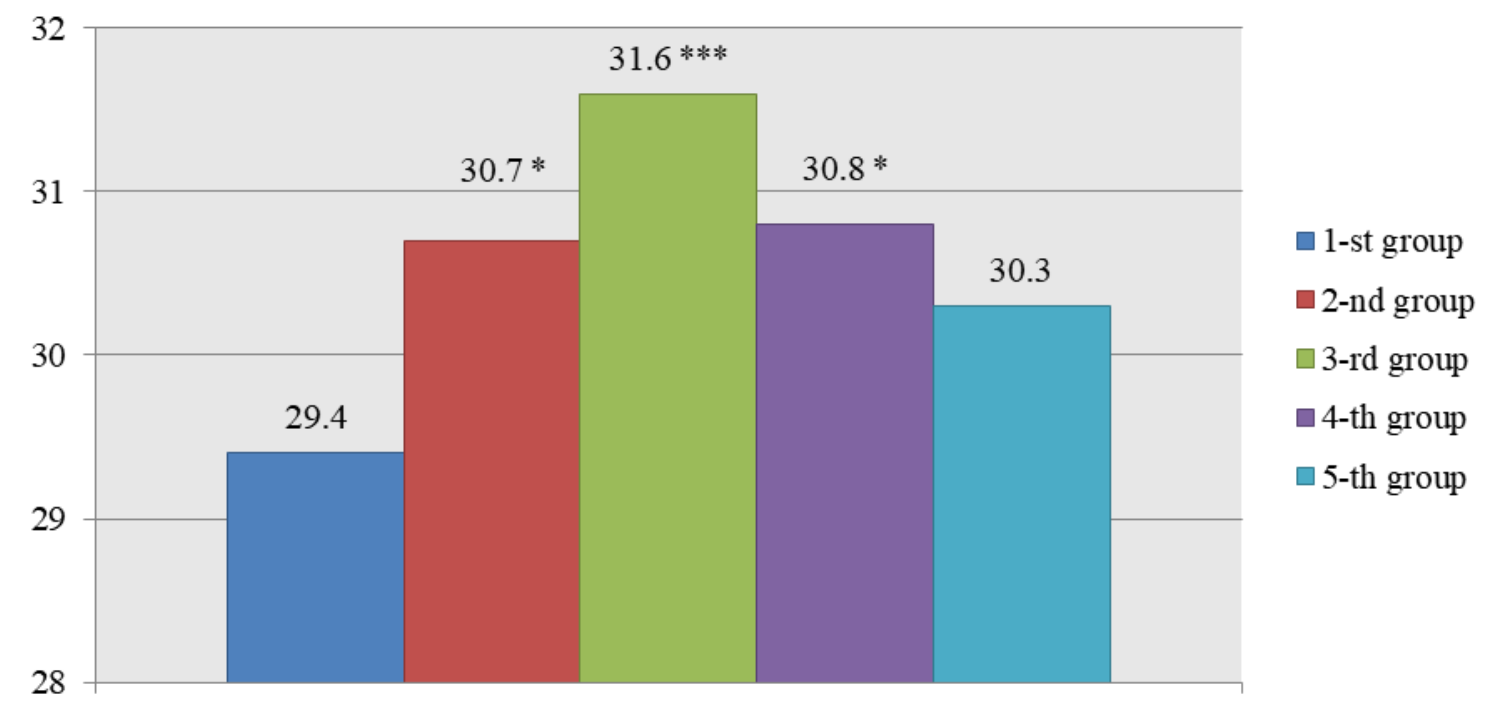

Figure 2. Average daily increments of the rabbits during the experiment, $g$

\section{DISCUSSION}

Main adsorption of Cadmium occurred in the gastrointestinal tract. Redused level of Cadmium ficsation contributed not only to the reduction of the accumulation of this element in the body, but also to decrease its negative influence on individual organs and tissues of rabbits. Animal and in vitro studies suggest that the absorption of $\mathrm{Cd}$ in the gastrointestinal tract is mediated by several transporter systems, which may include divalent metal transporter1, DMT1 (Garrick et al. 2003). Absorption rates for dietary $\mathrm{Cd}$ are influenced by the intake levels and body content of vital metals and elements. 
Higher dietary zinc intake levels were associated with lower Cd body burden, as assessed by urinary Cd excretion levels (Vance, et al., 2015).

The data of the Cadmium accumulation level in the body of experimental rabbits. As it can be seen, with the increase of the proportion of dry beet pulp in the mixed fodder, the level of Cadmium consumption in the body of rabbits decreased. Moreover, the amount of Cadmium fixation in the rabbit organism was inversely proportional to the content of dry pulp in the feed. The majority of reported dietary $\mathrm{Cd}$ intake estimates are within the FAO/WHO tolerable level of $58 \mu \mathrm{g} /$ day for a $70-\mathrm{kg}$ person, with an exception for certain locations in Japan, where intake exceeded the FAO/WHO safe intake guideline (Ikeda, et al., 2015). In particular, the increase of the dry beet pulp mass fraction in the mixed fodder up to $3 \%$ resulted in the increase of the average daily increment of the rabbit's body weight, while the rabbits of the 2 nd experimental group, compared with control one, increased body weight by $4.4 \%$. With $6 \%$ of mass fraction of dry pulp in mixed fodder, the average daily increment of the rabbits' body weight of the 3rd experimental group was the highest - $31.6 \mathrm{~g}$, which is higher than in the control group by $7.5 \%$. The average daily increments, the mass of the rabbit's body of the 4th and 5th experimental groups, with the mass fraction of dry pulp in the mixed fodder 9 and $12 \%$, exceeded the control group, by 4.8 and $3.1 \%$ respectively. The best rabbits' productivity was noted in the rabbits of the 3rd experimental group with the $6 \%$ mass fraction of dry pulp in mixed fodder. The body content of $\mathrm{Cd}$ assessed by urinary and/or blood Cd levels showed an inverse association with body mass index (BMI), central obesity, and risks of weight gain, and obesity in both children and adults. These have consistently been observed across populations, including the U.S., Belgium, Canada, Korea, and China. In a Chinese study, urinary $\mathrm{Cd}$ levels that were equivalent to or greater than 2.95 $\mu \mathrm{g} / \mathrm{g}$ creatinine were associated with a reduced risk of being overweight (Nie et al., 2016).

The introduction of dry beet pulp into the fodder of rabbits of the 2 nd experimental group in an amount of $3 \%$ by weight contributed to a decrease of the Cadmium content in the kidneys, liver, bones and meat, respectively, by $9.4 \% ; 16.0 ; 11.1$ and $13.9 \%$ compared to the rabbits of the control group. The increase in the mass fraction of dry beet pulp in the mixed fodder of rabbits of the $3 \mathrm{rd}$ experimental group up to $6 \%$ resulted in a decrease in the Cadmium content in meat by $22.3 \%$, liver by $20 \%$, in kidneys by $19.1 \%$, in bones by $17.6 \%$ relatively to benchmarks. A significant decrease in the level of Cadmium in slaughter products was noted in the animals of the 4th experimental group. Thus, they outperformed the control analogues with Cadmium in the kidneys, liver, bones and meat, respectively, by
$21.3 \% ; 28.8 ; 26.1$ and $27.9 \%$. The introduction of the $12 \%$ of dry pulp into the mixed fodder of rabbits in the 5th experimental group reduced the Cadmium content in meat by $33 \%$ compared to the control animals. However, Cadmium content in the kidneys decreased by $30 \%$, in the liver - by 39\%, in bones - by $29 \%$. In the Swedish study, a half of total kidney Cd content $(10 \mu \mathrm{g} / \mathrm{g}$ kidney cortex $)$ was estimated to come from food consumption, and the other half was attributed to cigarette smoking. The majority of subjects with high kidney Cd levels $(>50 \mu \mathrm{g} / \mathrm{g})$ were women (Elinder, et al., 1976).

In conclusion, the addition of dry beet pulp into the mixed fodder for rabbits, which are grown for meat, in an amount from 3 to $12 \%$ by weight, reduced the absorption of Cadmium in their bodies and reduced its content in slaughter products (kidney, liver, bone, meat), that increased their quality and environmental safety. In conclusion, the course of the experiment, it has been established that supplementation into the rabbit's mixed fodder of dry beet pulp contributes to reducing the level of Cadmium accumulation in slaughter products.

\section{ACKOWLEDGEMENT}

The current study was performed at the Experimental Animal Research farm of Bila Tserkva National Agrarian University Ukraine after the approval of the Local Ethics Committee of the Faculty of Veterinary Medicine under approval No: 00001/01;dated: 30/05/2016.

Conflict of Interest: The authors declare that they have no conflict of interest.

\section{REFERENCES}

Bonnie L. Carson, Harry V. Ellis III, Joy L. McCann. Toxicology Biological Monitoring of Metals in Humans, 2018; CRC Press

Chen X., Zhu G., Jin T., Qin B., Zhou W., Gu S. Cadmium is More Toxic on Volume Bone Mineral Density than Tissue Bone Mineral Density. Biol. Trace Elem. Res., 144: 380-387.

Council Regulation (EC) № 1099/2009 of 24 September 2009 on the protection of animals at the time of killing Official Journal of the European Union, 2011; 52: 1-30.

Dyachenko L, Syvyk T, Kosyanenko O. Influence of different levels of Cadmium in ration with natural detoxicant on performance, digestibility of substances and metabolism of nitrogen in young fattening pigs. J. Tech of produc and processing of animal products: Collection of scientific works of Bila Tserkva National Agrarian University, 2015; 1 : 163-168. 
Dyachenko L.S., Syvyc T.L., Tytariova O.M., Kuzmenko O.A., Bilkevich V.V. Natural detoxicants in pig rations and their impact on productivity and quality of slaughter products. Ukrainian J of Ecology, 2017; 7, (2) :239-246.

Elinder, C.G.; Lind, B.; Kjellstorm, T.; Linnman, L.; Friberg, L. Cadmium in kidney cortex, liver and pancreas from Swedish autopsies: Estimation of biological half time in kidney cortex, considering calorie intake and smoking habits. Arch. Environ. Health 1976, 31, 292301.

Garrick, M.D.; Dolan, K.G.; Horbinski, C.; Ghio, A.J: A mammalian transporter for multiple metals. Biometals 2003, 16, 41-54

Ikeda, M.; Nakatsuka, H.; Watanabe, T.; Shimbo, S. Estimation of daily cadmium intake from cadmium in blood or cadmium in urine. Environ. Health Prev. Med. 2015, 20, 455-459

Johri N, Jacquillet G, Unwin R. Heavy metal poisoning: the effects of cadmium on the kidney. Biometals, 2010; 23(5): 783-92

Khotimchenko M.Yu., Kolenchenko E.A. Efficiency of low-esterified pectin in toxic damage to the liver inflicted by lead treatment. Bulletin of Experimental Biology and Medicine, 2007; 144 (1) : 60-62

Kirsten $\mathbf{T}$ Eriksen, Jytte Halkjær, Jaymie $\mathbf{R}$ Meliker. Dietary cadmium intake and risk of prostate cancer: a Danish prospective cohort study. BMC Cancer, 2015; 15 : 177.

Maertes L. Nutritive value of raw materials for rabbits: World rabbits sci., 2004; 10: 157-166.

Mehrdad Rafati Rahimzadeh, Mehravar Rafati Rahimzadeh. Cadmium toxicity and treatment: An update. Caspian J Intern Med, 2017; 8(3): 135-145.

McLaughlin, M.J.; Singh, B.R. Cadmium in soils and plants. In Developments in Plant and Soil Sciences; McLaughlin, M.J., Singh, B.R., Eds.; Kluwer Academic Publishers: Dorddrecht, The Netherlands; Boston, London, 1999; Volume 85, pp. 1-7.

Nordberg GF. Cadmium and health in the 21 st century-historical remarks and trends for the future.Biometals, 2004; 17: 485-489

Nie, X.; Wang, N.; Chen, Y.; Chen, C.; Han, B. Blood cadmium in Chinese adults and its relationships with diabetes and obesity. Environ. Sci. Pollut. Res. Int. 2016, 23, 18714-18723.

Vance, T.M.; Chun, O.K. Zinc intake is associated with lower cadmium burden in U.S. adults. J. Nutr. 2015, 145, 2741-2748.
Pehlivan E., $\quad$ Yanık B.H., $\quad$ Ahmetli G., Pehlivanc M. Equilibrium isotherm studies for the uptake of cadmium and lead ions onto sugar beet pulp. Bioresource Technology, 2008; 99 (9): 3520-3527.

Scott V. Adams, Sabah M. Quraishi, Martin M. Shafer. Dietary Cadmium Exposure and Risk of Breast, Endometrial, and Ovarian Cancer in the Women's Health Initiative. Environ Health Perspect, 2014;122 (6): 594-600.

Temiraev R.B., Kozhokov M.K., Cherchesova S.K., Kokaeva F.F., Tletseruk I.R. Method for diminishing the adverse effect of anthropogenic heavy metal pollution on poultry meat products Journal of Environmental Management and Tourism, 2017; 3(19): 567-573.

Wu X, Samuel J. Cobbina, Guanghua Mao. A review of toxicity and mechanisms of individual and mixtures of heavy metals in the environment. Environmental Science and Pollution Research, 2016; 23 (9): 8244-8259. 